Volodymyr Yavorivsky. The Chornobyl Madonna. Translated from the Ukrainian by Yuri Tkacz, Bayda Books, 2016. 192 pp. Paper.

\title{
Valeriy Shevchuk. Breath of Evil: Novellas Written by the Goatherd Ivan Shevchuk and Fashioned for Literary Use by His Great-Grandnephew.
}

Translated from the Ukrainian by Yuri Tkacz, foreword by Marko R. Stech, Bayda Books, 2016. 246 pp. Paper.

$\mathbf{T}$

he books under review, both translated by Yuri Tkacz, are important monuments of mid-1980s Ukrainian literature. They are outstanding examples, respectively, of two distinct transformations of the Ukrainian cultural sphere-one at a time overlapping with Gorbachev's era of glasnost (hlasnist') and the other during the closing years of what is generally viewed as the period of Brezhnevian stagnation.

Volodymyr Iavorivs'kyi's novel Mariia z polynom u kintsi stolittia: Roman (Maria and Wormwood at the End of the Century: A Novel), published in 1987, was a direct and early response to the Chornobyl nuclear disaster. Based on the author's personal in situ interview research, the novel took literally the licence implicit in the very term hlasnist' by voicing criticism of the systemic failure of Soviet socialism and of the distempers of Soviet society. An activist novel by intention, it added substantial impetus to a wave of ecological protest, which, already germinating in the USSR, became one of the leading focuses of the civil society mobilization that contributed to the demise of the Soviet regime.

Valerii Shevchuk's Dim na hori: Roman-balada (House on the Hill: A Novel-Ballad), first published in 1983 but composed sporadically, as the author later attested, over the period of more than a decade during which he endured official disfavour and was not published, is a very different work. Seemingly inoculated against ideological impropriety by its eschewal of reference, direct or allegorical, to politics, the novel is deeply political in subtext, challenging the Soviet world view and, particularly, its colonialist dimensions. Part 1 of the novel (Shevchuk, Dim 4-235), the story of successive generations of women inhabiting a solitary house on a hill, becomes a mythical narrative about the human capacity for regeneration despite the predations of history and circumstance. The story is also a reflection in a somewhat Manichaean vein upon the random, yet equally salient, intrusions of forces of good and evil into the human world. Part 2 (Shevchuk, Dim 236-467; the part translated as the book Breath of Evil) is a cluster of novellas. Gothic in temperament, it utilizes socio-historical, cultural, and folkloric motifs from seventeenth-century Ukraine as material for the elaboration of a model of reality in which the numinous is as palpable 
as the material and the balance between light and dark struck in the first part has shifted emphatically toward darkness. The novel simply ignores the materialist orientation that, it seemed, was a prerequisite for products of Soviet culture. And its refusal to cast Ukrainian history and folklore in a comic, self-deprecating Gogolian fashion ignores the colonial hierarchy, in which seriousness and significance were reserved for the metropolitan, imperial culture.

It is easy to focus on both books' historical roles as exemplary, indeed innovative, works. But they are also works that are splendidly, if very differently, written. Tkacz does justice to each. Iavorivs'kyi's contribution is a tremendously busy piece of prose, racing to do justice to numerous "hot topics" ("hostri temy") all at once: major social problems (alcoholism, patriarchal condescension toward women, and the decline of rural communities); Soviet governance culture (careerism, nepotism, and cronyism; professional incompetence, bravado, and negligence; and, in the event of adversity, blame-shifting and cover-up as the default response); and the crisis that Iavorivs'kyi sees as despoiling intimate human relations (egotism, failure of trust, and licentiousness). This heady thematic mix is given shape by the distribution of various of its elements across the personal lives of a single, large family, the Myrovyches, headed by the Maria of the title, whose various sons, daughters, in-laws, and grandchildren are connected to, and afflicted by, the delinquent reactor.

It is a fast-paced text, with much of its energy emanating from the robust dialogue, which Tkacz is adept at rendering into natural-sounding English. Iavorivs'kyi, in his efforts to emphasize the weight of his subject matter, perhaps errs on the side of excessive symbolic signalling: in addition to Maria, the idealized font of family love and trust, there is the omnipresent "chornobyl" weed (the nuclear station itself is never named)-wormwood (called "mugwort" by the translator in a footnote [see Yavorivsky, Chornobyl Madonna 9, note 1]), whose associations in the Apocalypse readers need to look up for themselves; the Ferris wheel that runs amok; the funeral of Ivan, Maria's husband and the patriarch of the Myrovych clan, which is the last occasion that brings the family together while its members are all still alive and whole, before the nuclear disaster kills, maims, disgraces, bereaves, or renders homeless various of their number; the fact that the root of the surname Myrovych is myr, an archaism for world (this family is pars pro toto for the world, or, at least, the Soviet world); and, finally, Mavra the cow, rendered incapable of providing nourishment for humans owing to the recklessness of those very humans. Still, Iavorivs'kyi writes vividly, and Tkacz is able to match him: 
Людмила хоче провітрити кімнату. Відсовує важку оксамитову штору і відсахується від балконного вікна: величезна драглиста хмара з-над станції піднімається в небо, за нею тягнеться стовп чорного диму, фосфоричного вогню. До кімнати ввірвалося холодне, здається, душу пронизує, як рентген, світло. (Iavorivs'kyi, Mariia 90-91)

Liudmyla, wanting to air out the room, drew back the heavy velvet curtain and recoiled from the balcony window: an enormous gelatinous ball was rising into the sky over the power station, drawing with it a pillar of black smoke and phosphorescent fire. The room filled with a cold light, which seemed to pierce her soul like an x-ray beam. (Yavorivsky, Chornobyl Madonna 82)

Tkacz is a translator of great experience with more than thirty translated books to his name since the early 1980s, the majority by Ukrainian prose writers of the twentieth century. As he informed this reviewer, he undertook his translation in consultation with Iavorivs'kyi while Iavorivs'kyi worked on a revised version of his text, which, though completed, never saw publication in Ukraine; Tkacz's translation is its sole published record. One readily sympathizes with the translator in his decision to seek a title alternative to Maria and Wormwood. Nonetheless, the title The Chornobyl Madonna, however appropriate to the book's content, is perhaps not the best choice, given the existence of another well-known work inspired by ChornobylIvan Drach's long poem "Chornobyl's'ka madonna."

A similar question is raised by the title Breath of Evil. Part 2 of Shevchuk's novel Dim na hori is entitled "Holos travy" ("Voice of the Grass"); this is also the title, in the novel's first edition, of the splendid final novella, which serves as a kind of philosophical coda for the work as a whole. An old sorceress is sought out by a youth who feels called to learn her wisdom, which she encapsulates as the rare capacity to hear the "voice of the grass"-to apprehend the spirit that imbues Nature, pantheistically imagined. Even though she knows that the transfer of her insight to another will lead to her own death, she acquiesces, only to discover that the questing youth is, in fact, another sorceress, her chief antagonist, in disguise. The plot neatly summarizes the novel's overall argument concerning the cyclicity of things cosmic and human and the inextricable mutual involvement of good and evil. But, as suggested above, by themselves, the novellas of the second part of Dim na hori subtend the image not of a world in balance between light and dark and good and evil but, rather, of a world thoroughly bedevilled and bewitched, where the human being is offered only doubt, bewilderment, fear, melancholy, and despair as modes of existence. Breath of Evil is not a bad title for such a collection. 
More generally: Is Tkacz justified in offering to the public only half of Shevchuk's novel? Against such a course, understandably, is the argument that the aesthetic purpose of the novel lies precisely in its structural dualism, which echoes the dualistic world view that the author articulates in the novel as a whole. In practice, translating the text in full would have produced a very long book, whose first part-placid, serene, slow-paced, and evidently imbued with symbolic clues but resistant to ready decoding-would likely have proved challenging for readers seeking acquaintance with an unfamiliar literature. Tkacz chose to present the part of the novel that can more readily be slotted into categories familiar to readers who are versed in the general European literary tradition, historical and contemporary-that is, the Gothic and magic realism.

Shevchuk's work presents the translator with more challenges than does Iavorivs'kyi's novel. At the basic level, there is the question of vocabulary. What near-equivalents should one find for the various figures of Slavic demonology? Tkacz's "hobgoblin" (see Shevchuk, Breath 12-24) works well for "domovyk" (see Shevchuk, Dim 238-50), but "incubus demon" (see Shevchuk, Breath 80-92) sounds more like a definition than an equivalent of "perelesnyk" (see Shevchuk, Dim 309-21). The same is true for words indicating social standing. "Lord Yuri" (see, e.g., Shevchuk, Breath 12) implies membership in a much more restricted and elevated aristocratic estate than does the "pan Iurii" of the original (see, e.g., Shevchuk, Dim 238): the nobility of the Polish-Lithuanian Commonwealth, who were entitled to be addressed as "pan" or "pani," were a rather substantial part of the population. To take another example, the familiar and slightly vulgar timbre of "Zhabunykha," literally "wife of Zhabun" (see, e.g., Shevchuk, Dim 430), is certainly not replicated by the genteel "Mrs Zhabun" (see, e.g., Shevchuk, Breath 199). Such things, perhaps, are the inevitable losses of translation. One loss, though, is unforced and occasionally affects the tone of the volume. Shevchuk's style is serious, indeed solemn, throughout; the dialogue is not an imitation of individualized speech but a generalized diction that-where it is not distinctly sonorous and lofty-is, at least, neutral. Colloquialism, to which Tkacz frequently resorts, constitutes a breach of this style. "Me neither" and "Know why?" (Shevchuk, Breath 12,13) are not suitable renderings of "Ia takozh" and "A znaiete chomu?" in this context (Shevchuk, Dim 239, 240), where the plain phrases "Nor I" and "Do you know why?" would have remained within the right register.

These, however, are quibbles. In general, Tkacz captures the rhythm and the atmospherics of Shevchuk's prose rather well, as the following may illustrate: 
Було в той день похмуро. Звисали над землею темними рядами хмари, а за горбами товклися, наче поспішали якнайшвидше сховатися за окоєм. Земля дрімала в сірому світлі, ця сірість уливалась у душі людей, і всі ходили трохи роздратовані. (Shevchuk, Dim 239)

It was gloomy that day. Clouds hung low over the earth in dark rows, and they pushed and shoved above the hills, as if rushing to hide behind the horizon. The earth slumbered in the grey light, the greyness poured into people's souls and everyone went about their business slightly irritated. (Shevchuk, Breath 13)

In short, Tkacz has given us two readable, indeed exciting, well-executed translations of notable Ukrainian literary texts that are representative of a period of cultural transformation. General readers, as well as designers of courses of Ukrainian literature in English, should take note.

Marko Pavlyshyn

Monash University

Works Cited

Drach, Ivan. “Chornobyl's'ka madonna.” Vitchyzna, 1988, no. 1, pp. 42-62.

Iavorivs'kyi, Volodymyr. Mariia z polynom u kintsi stolittia: Roman. Vydavnytstvo khudozhn'oi literatury “Dnipro," 1987. Romany i povisti 1987/11.

Shevchuk, Valerii. Dim na hori: Roman-balada. Afterword by Mykola Zhulyns'kyi, Vydavnytstvo "Radians'kyi pys'mennyk," 1983. 